\title{
DATING OF THE UDIN BORŠT CONGLOMERATE TERRACE AND IMPLICATION FOR TECTONIC UPLIFT IN THE NORTWESTHERN PART OF THE LJUBLJANA BASIN (SLOVENIA)
}

\author{
DATACIJA KONGLOMERATNE TERASE UDIN BORŠT IN NJENA \\ UPORABA ZA DOLOČITEV TEKTONSKEGA DVIGOVANJA \\ V SEVEROZAHODNEM DELU LJUBLJANSKE KOTLINE \\ (SLOVENIJA)
}

\author{
Andrej MIHEVC ${ }^{1}$, Miloš BAVEC 2 , Philipp HÄUSELMANN² \& Markus FIEBIG ${ }^{4}$
}

\begin{abstract}
UDC 552.512:551.44(497.4Udin boršt)

Andrej Mihevc, Miloš Bavec, Philipp Häuselmann \& Markus Fiebig: Dating of the Udin Boršt conglomerate terrace and implication for tectonic uplift in the northern part of the Ljubljana Basin (Slovenia)

The northwestern part of the Ljubljana Basin is filled mostly with fluvioglacial sediments deposited by rivers coming from Alpine mountain groups. The Tržiška Bistrica River, flowing from the Karavanke Mountains, has deposited a large alluvial fan consisting predominantly of carbonate pebbles with subordinate amounts of siliciclastic pebbles. The oldest infill, cemented into a conglomerate terrace named Udin Boršt, overlies an erosional surface on Oligocene mudstone. The thickness of the conglomerate terrace is up to $50 \mathrm{~m}$. The conglomerate terrace is well karstified; the surface is dissected by numerous dolines and covered with a thick soil sequence. There are several caves. The most important are spring caves formed on the contact with the underlying impermeable basement. Samples of quartz pebbles were taken from the walls and ceiling in the $815 \mathrm{~m}$ long spring Arneševa Luknja Cave for cosmogenic nuclides burial age dating. The calculated burial age yielded an age of $1.86 \pm 0.19 \mathrm{Ma}$ that gives (i) the age of the oldest known infill in the Ljubljana Basin and (ii) indicates the time of change of the sedimentary system in the Basin from erosion to deposition. The age of the Udin Boršt karst and caves is significantly younger. The age dates provide grounds for a first relatively firm estimate of the long-term tectonic uplift of the Udin Boršt terrace to be between 0.06 and $0.04 \mathrm{~mm} / \mathrm{yr}$. This tectonic uplift rate may be related to the activity of the regional Sava Fault. Keywords: conglomerate river terrace, burial age dating, ${ }^{10} \mathrm{Be}-{ }^{26} \mathrm{Al}$, tectonics, uplift rate, Pleistocene, cave, Southern Alps.
\end{abstract}

\begin{abstract}
Izvleček
UDK 552.512:551.44(497.4Udin boršt) Andrej Mihevc, Miloš Bavec, Philipp Häuselmann \& Markus Fiebig: Datacija konglomeratne terase Udin boršt in njena uporaba za določitev tektonskega dvigovanja v severozahodnem delu Ljubljanske kotline (Slovenija)

Severozahodni del Ljubljanske kotline pokrivajo večinoma fluvioglacialni sedimenti, ki so jih odložile reke iz alpskih gorskih skupin. Tržiška Bistrica, ki priteka iz Karavank je odložila velik vršaj. V njem prevladujejo karbonatni prodniki z manjšim deležem siliciklastičnih prodnikov. Ta najstarejša zapolnitev, sprijeta v konglomeratno teraso Udin boršt, leži na erozijskem površju oblikovanem v oligocenskih glinovcih. Debelina konglomeratne terase je do $50 \mathrm{~m}$. Konglomeratna terasa je dobro zakrasela, površje pa je razčlenjeno $\mathrm{z}$ vrtačami in pokrito $\mathrm{z}$ debelo plastjo prsti. V njej je več jam, med katerimi so najpomembnejše izvirne jame, ki so se oblikovale na stiku z neprepustno podlago. V $815 \mathrm{~m}$ dolgi Arneševi luknji smo vzeli iz sten in stropa jame vzorec iz kremenovih prodnikov za določitev pokopne starosti prodnega zasipa s kozmičnimi nuklidi. Izračunana starost prekritja sedimentov je $1.86 \pm 0.19 \mathrm{Ma}$. Ta datacija določa (i) starost najstarejše sedimentne zapolnitve $\mathrm{v}$ Ljubljanski kotlini in (ii) čas spremembe v sedimentacijskem sistemu kotline iz erozije v sedimentacijo. Starost kraških oblik in jam v Udin borštu je znatno mlajša. Starost sedimenta daje tudi osnovo za relativno trdno določitev tektonskega dviga terase Udin boršta na 0,06 do $0,04 \mathrm{~mm} / \mathrm{yr}$. Ta tektonski dvig je verjetno povezan $\mathrm{z}$ premiki ob regionalnem savskem prelomu. Ključne besede: konglomeratna rečna terasa, pokopna starost, ${ }^{10} \mathrm{Be}-{ }^{26} \mathrm{Al}$, tektonika, hitrost dvigovanja, pleistocen, jama, Južne Alpe.
\end{abstract}

\footnotetext{
${ }^{1} 1$ Andrej Mihevc Karst Research Institute ZRC SAZU, Titov Trg 2, 6230 Postojna, Slovenia; e-mail: mihevc@zrc-sazu.si

${ }^{2}$ Philipp Haeuselmann, Schweiz. Inst. für Speläologie und Karstforschung, c.p. 818, 2301 La Chaux-de-Fonds, Switzerland; e-mail: praezis@speleo.ch

${ }^{3}$ Miloš Bavec, Geological Survey of Slovenia Dimičeva ulica 14, Ljubljana, Slovenia; e-mail: milos.bavec@geo-zs.si

${ }^{4}$ Markus Fiebig, University of Natural Resources and Life Sciences, Peter Jordan-Str. 70; A-1190 Wien; Austria;

e-mail: markus.fiebig@boku.ac.at
}

Received/Prejeto: 11.06.2015 


\section{INTRODUCTION}

The Ljubljana Basin is a tectonic basin formed along the Sava Fault between the mountain groups of the Julian Alps and the Karavanke Mountains (Placer 2008). It is filled with partly glacial, but mostly glaciofluvial and fluvial sediments deposited by the Sava River and its tributaries (Fig. 1). One of them, Tržiška Bistrica, flowing from the North to the basin, formed a complex system of terraces (Šifrer 1969).

Only a rough chronological framework of the terraces has been provided in the past by combining morphostratigraphic relationship (Penck \& Brueckner 1909; Žlebnik 1971), and application of ${ }^{10} \mathrm{Be}$ and paleomag- netic dating (Pavich \& Vidic 1993; Vidic \& Lobnik 1997, Vidic 1998) on the oldest terrace.

From the irregular terrace positions it has been suggested that, besides Pleistocene climate, tectonic movements represent an important factor of the terraces architecture. The dip of terrace surfaces in the basin north of Kranj City indicates inferred constant uplift from the time of deposition until the Late Pleistocene (Žlebnik 1971; Kuščer 1990).

Here we provide the burial age dating of the oldest fluvial sediment (so-called Older Conglomerate Infill; Žlebnik 1971) at the base of the terrace named Udin

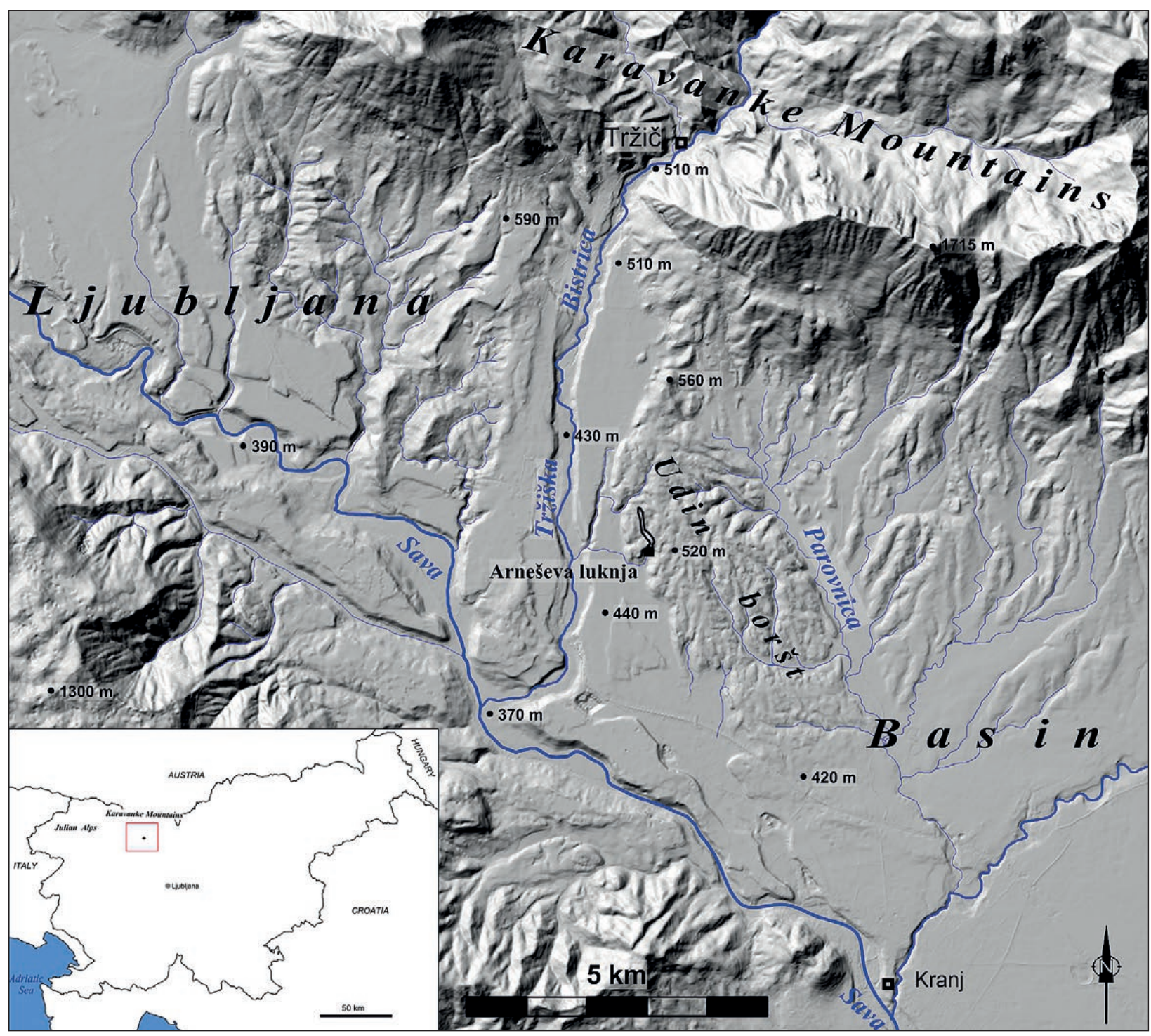

Fig. 1: Position of the study area and location of the Udin Boršt terrace and the Arneševa luknja Cave, where quartz pebbles were sampled. 
Boršt. The sediment was sampled in Arneševa Luknja Cave $\left(46^{\circ} 18^{\prime} 11^{\prime \prime} \mathrm{N} 14^{\circ} 18^{\prime} 9^{\prime \prime} \mathrm{E}\right)$ developed at the contact of terrace conglomerate with the basin non-carbonate basement (Gantar 1955; Gabrovšek 2005). The samples allow dating of what is presumably the oldest infill and contribute to dating of the change of geomorphic conditions in that part of the basin from erosion to deposition. This indicates the change of the tectonic style and/or one of the early glaciations. The dating simultaneously represents the first relatively firm estimate of the long-term uplift rate in this uplifting part of the northern part of the Ljubljana Basin. As the Ljubljana Basin is seismically active area (Ribarič 1982; Jamšek Rupnik et al. 2013), this is a helpful constraint for any further estimate of the seismic hazard.

\section{HYPOTHESIS}

Generally, samples for cosmogenic dating of caves focus on quartz that was washed from outside towards a limestone area and into its caves (Häuselmann \& Granger 2005). Dating of the sample gives the time since it has been washed underground, and thus a minimum age of the cave itself.

In the case of Udin Boršt, the aim is different. We assume that all the pebbles forming the conglomerate terrace had been transported by a river and thus acquired the necessary variation of cosmogenic nuclides prior to deposition. Udin Boršt deposits are $40-50 \mathrm{~m}$ thick (Prelovšek \& Slabe 2005), so the lowermost pebbles should have been shielded from further radiation after deposition. The Arneševa Luknja Cave then formed later on. If we sample quartz pebbles from the walls and the ceiling of the cave (more or less identical to the base of the terrace and thus the beginning of sedimentation), then their dating should give the maximum age or the beginning of terrace deposition and thus ideally set a marker in the Pleistocene history for that part of the Ljubljana Basin and Sava River Valley.

In this case, the dating of the terrace is basically similar to the age dating of caves, with only one sample needed. This is in strong contrast to dating shallower terraces, for instance the Günz and Mindel type localities in Southern Germany (Häuselmann et al. 2007), where a sampling profile along the terrace wall is needed to counter the effects of later erosion and post-burial production. It is thus most welcome to have caves at the terrace base. However, this fortunate circumstance, especially in quartz-bearing conglomerates, is rarely found.

\section{DESCRIPTION OF THE SITE}

The Tržiška Bistrica River that originates in the Karavanke Mountain Group has deposited a large alluvial fan into the northern part of the Ljubljana Basin. It consists mostly of limestone and dolomite pebbles and sands with an admixture of siliciclastic rocks. The central part of the alluvial fan later underwent several phases of erosion and deposition, so that the original surface of the alluvial fan is dissected with younger valleys and terraces. Simplified, the terrace system can be divided into four dominant surfaces (see Fig. 2), named traditionally (Žlebnik 1971) as the Older Conglomerate Infill (4), Middle Conglomerate Infill (3), Younger Conglomerate Infill (2), and finally a system of Younger gravel terraces (1). Surfaces with younger sediments are still smooth, while the surface of the oldest terrace is cemented and karstified.

The largest remnant of the oldest conglomerate terrace, Udin Boršt, is about $8 \mathrm{~km}$ long and $2.5 \mathrm{~km}$ wide.
The conglomerate of Udin boršt directly overlies the erosional surface formed on grey Eggerian (OligoceneMiocene) mudstone. These rocks are exposed by erosion on the sides of the Udin Boršt and also in some fluvial valleys that cut through the terrace (Figs. 3 and 4). The elevation of the terrace surface is about 560 m.a.s.l. on the north and 410 m.a.s.l. on the south, where it is covered with younger glaciofluvial gravels of the Sava River. The terrace has steep erosional scarps formed by Tržiška Bistrica River in the west and Parovnica River on the east.

The conglomerates of Udin Boršt are well karstified. The surface of the terrace is dissected by numerous dolines and covered by thick soils. There are also several caves.

A similar, but smaller, part of the conglomerate terrace is preserved also on the $\mathrm{W}$ side of Tržiška Bistrica River valley, at an elevation of about 590 m.a.s.l. (Fig. 4). 


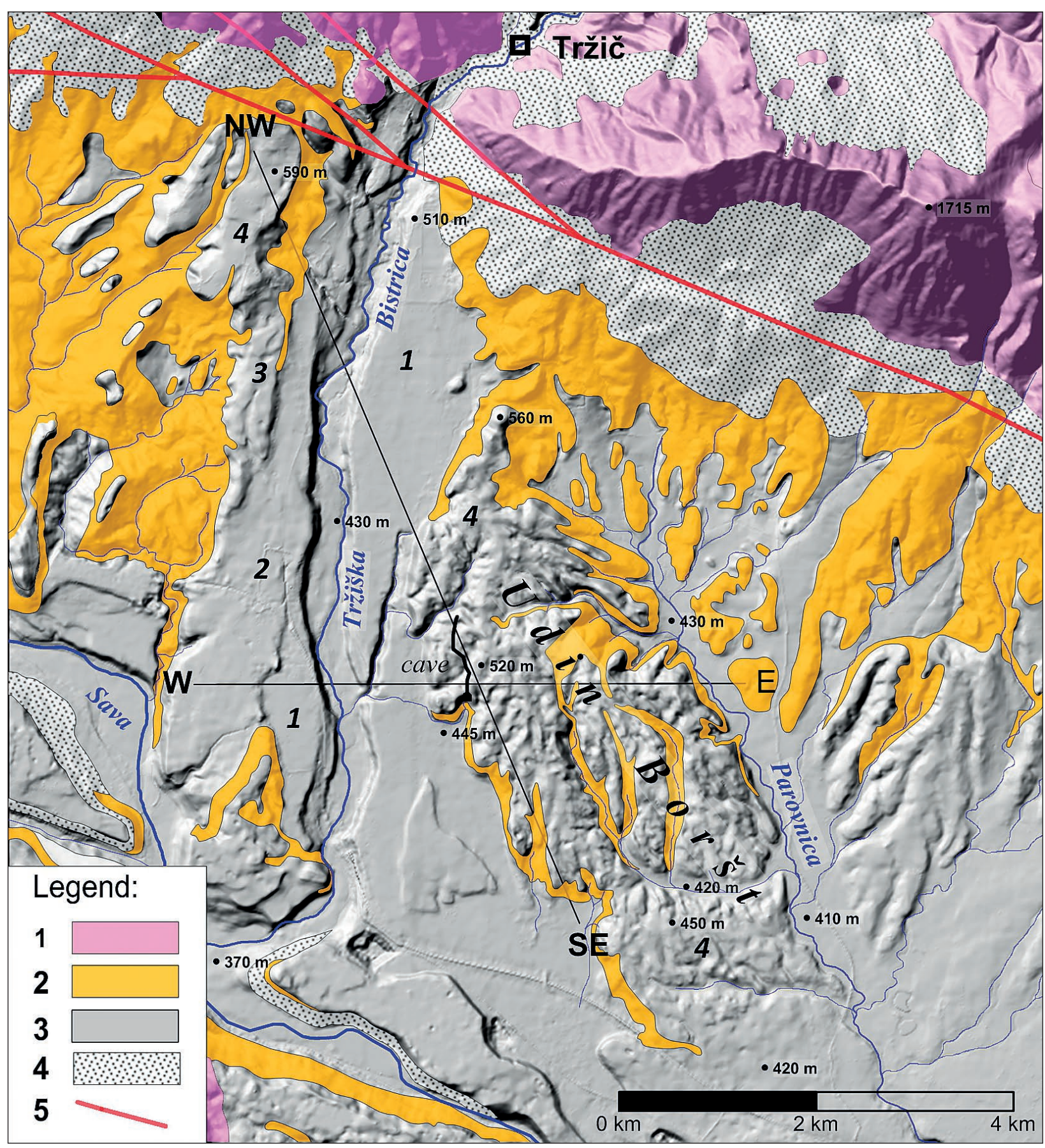

Fig. 2: DEM and simplified geologic map of the Udin Boršt and surroundings. Legend: 1. Mesozoic, mostly carbonate rocks of Karavanke; 2. Upper Oligocene mudstones; 3. Pleistocene and Holocene fluvial and glaciofluvial sediments; 4. Youngest Holocene gravels, scree material; 5. Sava Fault. Lines marked W-E and NW-SE show the position of two profiles (Figs. 2 and 4). Numbers $1-4$ on the map are chronological estimations of the terraces described in the text. Geology after: Buser \& Cajhen 1978; Grad \& Ferjančič 1974; Jamšek et al. 2012; terrace chronology after: Žlebnik 1971).

The terrace is also karstified, and thick soil developed on surface of the terrace.

On the $\mathrm{W}$ side of Udin Boršt, four larger spring caves formed on the contact with underlying impermeable basement, which is also seen in the entrance parts of the caves. All caves dip from $\mathrm{N}$ to $\mathrm{S}$ following the dip of the basement rocks. The total length of their passages is over $2 \mathrm{~km}$.

The longest cave in the area, where we sampled the conglomerate, is $815 \mathrm{~m}$ long Arneševa Luknja Cave 


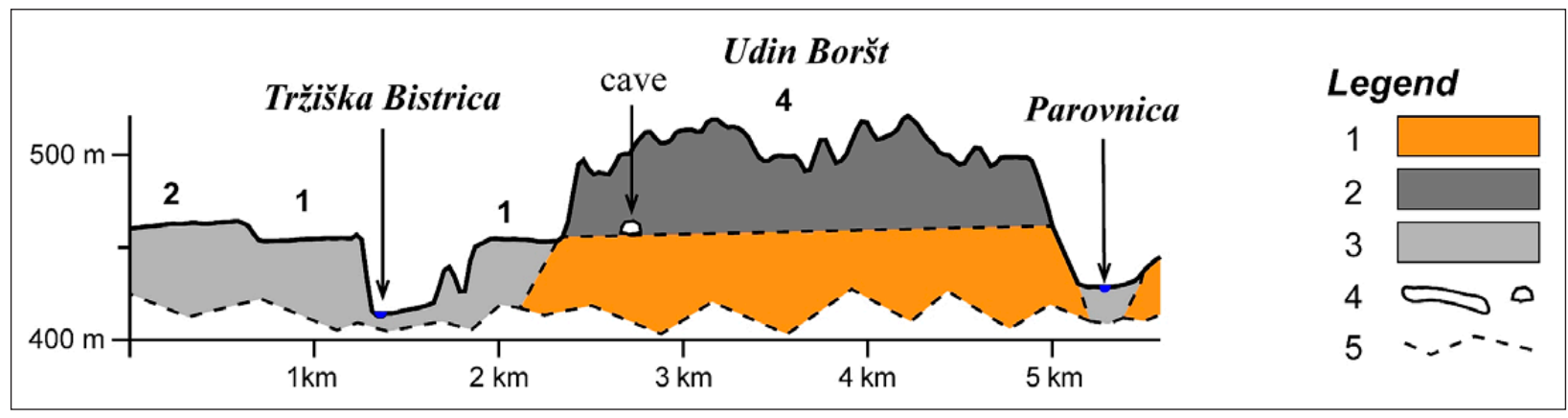

Fig. 3: Transverse W-E cross-section through Udin Boršt and the central part of the sedimentary complex of Tržiška Bistrica River. The Arneševa luknja Cave formed at the bottom part of the conglomerate terrace at the contact with underlying Oligocene mudstones. Quartz pebbles were sampled from the walls of the cave. 1: upper Oligocene mudstones; 2: Conglomerate; 3: Pleistocene and Holocene fluvial and glaciofluvial sediments; 4: outline of the Arneševa Luknja Cave, 5: erosional surfaces.

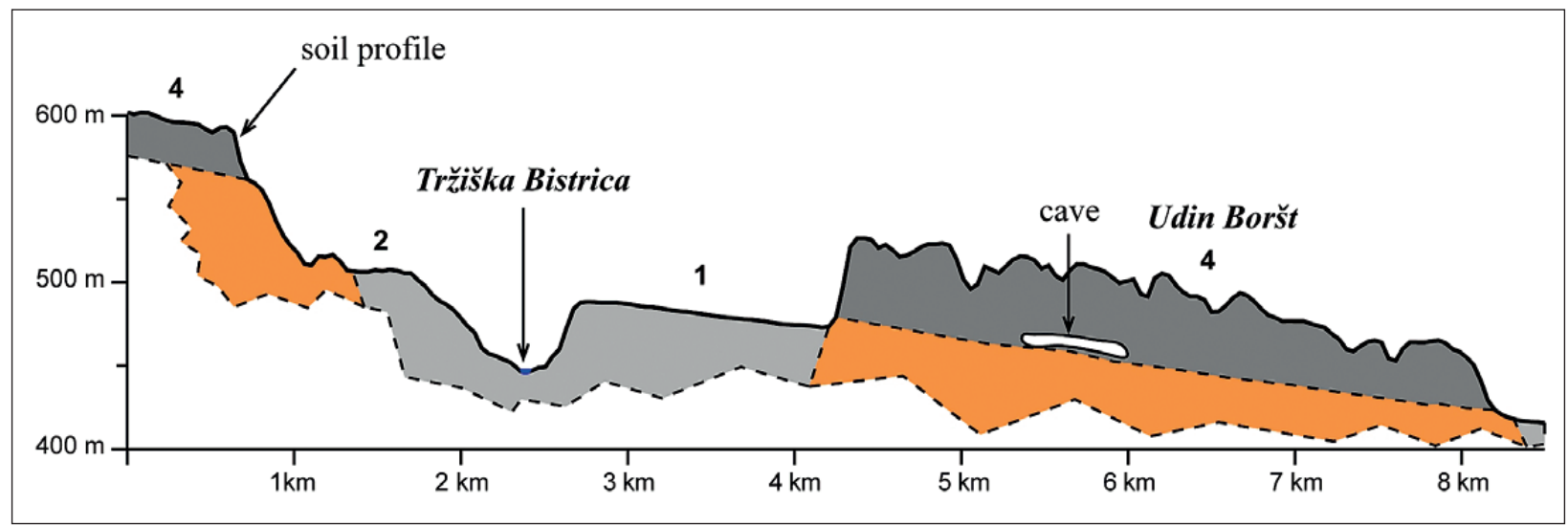

Fig. 4: Longitudinal NW-SE cross-section showing the remnants of conglomerate terrace (4) and younger glaciofluvial sediments (terrace 2 and 1) of the Tržiška Bistrica River. The arrow shows the sampling position of quartz pebbles in Arneševa Luknja Cave and the position where a soil profile was studied by Pavich \& Vidic (1993) on terrace No. 4. For legend see Fig. 3.

with a main passage that gently dips $\left(1-2^{\circ}\right)$ towards $S$. It is a spring cave formed by a small stream with a discharge of about $0.001 \mathrm{~m}^{3} \mathrm{~s}^{-1}$. The cave is formed in conglomerate just above (1-2 $\mathrm{m}$ at the entrance) the contact with grey mudstone. The Main Passage is generally low and narrow, reaching dimensions of several $\mathrm{m}$ high or wide in only a few places (Gantar 1955; Gabrovšek 2005). The entrance to the cave is at an elevation of 470 m.a.s.l. Above the cave, the surface is at an elevation of 510-540 m.a.s.l., so the cave has more than $40 \mathrm{~m}$ of conglomerate cover.
The sample for burial age dating (marked $\mathrm{HB}$ ) consists of small $(1-5 \mathrm{~cm})$ quartzite pebbles that were collected mainly from the walls and ceiling of the entrance part of the cave. Occasionally, larger pebbles were also sampled from the stream bed, with the idea that they were too large to have been imported from the surface. The cave stream itself originates from the percolating water within the conglomerate terrace and has only few smaller tributaries along its known course, so the possibility of contamination with quartzite pebbles of other origin is negligible.

\section{METHODS}

The burial age method involves the measurement of two isotopes $\left({ }^{26} \mathrm{Al}\right.$ and $\left.{ }^{10} \mathrm{Be}\right)$ that are produced by cosmic radiation in quartz near the surface prior to burial. ${ }^{26} \mathrm{Al}$ and ${ }^{10} \mathrm{Be}$ accumulate at a ratio of about $6.8: 1$ in quartz grains with a rate of a few atoms per gram of quartz per year. Sufficiently deep burial (more than $10 \mathrm{~m}$ ) of such quartz-rich sediment in a cave assures shielding from further cosmic rays. After burial the ${ }^{26} \mathrm{Al}$ and ${ }^{10} \mathrm{Be}$ concentrations in the 
sample are only affected by their relative decay resulting in a decrease in the ${ }^{26} \mathrm{Al} /{ }^{10} \mathrm{Be}$ ratio. This ratio measured can be used to derive a burial age (Gosse \& Phillips 2001; Granger \& Muzikar 2001). The current upper limit for measurement of the ${ }^{26} \mathrm{Al}$ and ${ }^{10} \mathrm{Be}$ isotope pair is around $5 \mathrm{Ma}$. A prerequisite of the burial dating technique is that samples have been exposed long enough to cosmic rays and accumulated sufficient cosmogenic nuclides prior to burial. Unfortunately this cannot be determined a priori in the field.

In the laboratory, about $100 \mathrm{~g}$ of quartz were extracted and purified from bulk samples by magnetic and density separation and selective chemical dissolution. Quartz was dissolved in a 5:1 solution of concentrated $\mathrm{HF}$ and $\mathrm{HNO}_{3}$ and spiked with about $0.35 \mathrm{mg}{ }^{9} \mathrm{Be}$. Al and Be were separated and purified by ion chromatography and selective precipitation. Precipitates were oxidized and mixed with metal powder for accelerator mass spectrometry (AMS). ${ }^{10} \mathrm{Be} /{ }^{9} \mathrm{Be}$ and ${ }^{26} \mathrm{Al} /{ }^{27} \mathrm{Al}$ nuclide ra- tios in the sample and procedural blanks were measured at Purdue University in West Lafayette (USA). Stable aluminium concentrations were determined by ICP-OES. The stated errors are $1 \sigma$ calculated from AMS and ICPOES uncertainties.

The isotope concentrations can also be used to infer paleo-erosion rates of the source area prior to burial of the clasts. This is accomplished by backward modelling the quantity of nuclides present prior to the burial coupled with local production rate estimates.

The pre-burial ${ }^{26} \mathrm{Al} /{ }^{10} \mathrm{Be}$ ratio (6.8:1) is basically not influenced by production rate and thus elevation (Nishiizumi et al. 1989; Stock et al. 2005) and therefore burial ages remain unaffected by altitude changes in the source area. Here we have to take in account that the pre-burial erosion rates are based on measured isotope concentrations and elevation dependent production rates. They are therefore only approximate.

\section{RESULTS}

The calculated burial age for sample HB yielded an age of $1.86 \pm 0.19 \mathrm{Ma}$ (Tab. 1).

The error of only $10 \%$ is quite small for burial age dating, especially as the sample is not very recent. How- ever, the large abundance of isotopes as well as the small error in dating indicates that the age as well as the error are reliable.

Tab. 1: The measured values of sample HB and the calculated ages (error 1 sigma).

\begin{tabular}{l|l|l|l|l|l|l|l|l}
\hline Cave & Sample & $\begin{array}{l}\text { Altitude of } \\
\text { catchment } \\
\text { (a.s.l.) }\end{array}$ & $\begin{array}{l}\text { Altitude in } \\
\text { cave } \\
\text { (a.s.l. })\end{array}$ & $\begin{array}{l}{ }^{26} \mathrm{Al} \\
\left(10^{3} \text { at } / \mathrm{g}\right)\end{array}$ & $\begin{array}{l}{ }^{10} \mathrm{Be} \\
\left(10^{3} \text { at } / \mathrm{g}\right)\end{array}$ & ${ }^{26} \mathrm{Al} /{ }^{10} \mathrm{Be}$ & $\begin{array}{l}\text { Burial age } \\
(\mathrm{Ma})\end{array}$ & $\begin{array}{l}\text { Pre-burial } \\
\text { erosion rate } \\
(\mathrm{m} / \mathrm{Ma})\end{array}$ \\
\hline Arneševa luknja & HB & 500 & 470 & $680 \pm 65$ & $256 \pm 8.19$ & $2.66 \pm 0.27$ & $1.86 \pm 0.19$ & $6 \pm 0.6$ \\
\hline
\end{tabular}

\section{DISCUSSION}

The deposition age of buried pebbles in the cave is 1.86 $\pm 0.19 \mathrm{Ma}$. This age indicates the end of erosion of the Oligocene grey mudstones and the onset of gravel sedimentation. This clear change may likely be the result of tectonic activity connected with the Sava Fault (Jamšek Rupnik et al. 2012), i.e. uplift of the mountains $\mathrm{N}$ of the fault and relative subsidence of the basin S of the fault, as interpreted before by Žlebnik (1971).

The age of Udin Boršt conglomerates may seem to be high for its position in a low-lying tectonic basin. Regarding the age of the sediment, there are two alternative interpretations, of which both indicate that $1.86 \pm 0.19 \mathrm{Ma}$ is merely the minimum age of its deposition. First is the intake of pebbles directly from the surface. These freshly imported pebbles would have a burial age close to zero, and an eventual mixing with the ones in situ would give younger actual ages. The other alternative could be a stepwise deposition of the pebbles with different hiatuses across the terrace. In this case, post-burial production would not be negligible and would result in a younger age. Therefore, we can confidently assert that 
the calculated age of $1.86 \pm 0.19 \mathrm{Ma}$ is the minimum age of the terrace formation.

On the $\mathrm{W}$ side of Tržiška Bistrica River valley, opposite to Udin Boršt, a smaller remnant of the same old conglomerate terrace is preserved. An attempt was made to date the soils that developed on this terrace (Fig. 2) prior to this work in the early years of cosmogenic dating (Pavich \& Vidic 1993; Vidic \& Lobnik 1997). With 10Be yielding the age of $>1 \mathrm{Ma}$ and paleomagnetic analysis showing the normal polarity chron prior to the Brunhes $(>0.78 \mathrm{Ma})$, the authors estimated the most likely time of deposition to be the age of the normal polarity during the Olduvai subchron at 1.78-1.98 Ma. This was further supported by the best statistical fit of time-dependent soil properties like soil thickness and clay mass (Pavic \& Vidic 1993). Our study shows that their assumption was correct and that we now can make a rough estimate of the uplift rate in the area.

The surface of the dated Udin Boršt terrace is at 564 m.a.s.l. If we suppose that the river level remained the same throughout the Pleistocene, then the difference with the modern river bed (at $445 \mathrm{~m}$ ) gives an uplift rate of $0.06 \mathrm{~mm} \cdot \mathrm{a}^{-1}$. If we take into account Kuščer's (1990) estimate that the uplift has stopped during the Late Pleistocene, and if we adopt the age of the Late Glacial Terrace (at 485 m.a.s.l.; Fig. 2) to be in line with Pavich and Vidic's estimates $(<70 \mathrm{ka})$ and not younger than the Last Glacial Maximum, the uplift rate is then estimated to be at $0.04 \mathrm{~mm} \cdot \mathrm{a}^{-1}$. One has to note: a) that these two estimates attribute all relief to tectonic uplift, and that there may be other controlling factors that interfere with this phenomenon; and b) that more recent geodetic measurements indicate ongoing uplift in the area (Rižnar et al. 2005; Serpelloni et al. 2013).

The age of the buried pebbles can give only the maximum possible age of the Arneševa Luknja Cave and other caves. The formation of caves at the contact with the basement and dolines on the terrace surface must be much younger. They could have been formed only after the cementation of gravels of terrace to conglomerate which could happen after the incision of the Tržiška Bistrica River and other rivers on sides of Udin Boršt terrace below into the Oligocene basement.

\section{CONCLUSION}

Cosmogenic burial age dates of quartz pebbles extracted from the walls of the Arneševa Luknja Cave give the minimum age of the alluvial fan of Tržiška Bistrica River and the maximum age of cave formation in Udin Boršt. The formation of this conglomerate terrace is related to tectonic and geomorphic evolution at the contact of Ljubljana Basin and Karavanke Mountain Group along the active Sava Fault.

The main conclusions can be briefly listed as follows:

- The burial age of pebbles sampled in the cave that formed at the base of the infill is $1.86 \pm 0.19 \mathrm{Ma}$.
- Near Udin Boršt, the tectonic uplift rate is estimated to be between 0.06 and $0.04 \mathrm{~mm} / \mathrm{yr}$, controlled by a large scale tectonic background related to displacement along the active regional Sava Fault.

- Erosion of the alluvial fan was controlled mostly by erosion and deposition of the last Pleistocene climatic cycles.

- The age of the Udin Boršt karst and caves is significantly younger than $1.86 \pm 0.19 \mathrm{Ma}$.

\section{ACKNOWLEDGEMENTS}

First thanks go to Herta Effenberger (University of Vienna) who let us use space for a laboratory, as well as the whole Geozentrum at Vienna University for the help and welcome to our project. The PrimeLab of Purdue University (Indiana, USA) is thanked for sample processing and measuring the isotopes. We thank Carol Ramsey for revising the English in text. Finally, the Austrian Fund for Scientific Research FWF is thanked for funding the project (P 19362-N10) as well as Slovene Research Agency for funding the projects L1-2383 and P1-0011. 


\section{REFERENCES}

Buser, S. \& J. Cajhen, 1978: Osnovna geološka karta SFRJ, 1:100.000. List Celovec (Klagenfurt), Zvezni geološki zavod, Beograd.

Gabrovšek, F., 2005: Jame v konglomeratu: primer Udin Boršta, Slovenija. Caves in conglomerate: case of Udin Boršt, Slovenia.- Acta carsologica, 34(2), 507519.

Gantar, J., 1955: Arneševa luknja.- Acta carsologica, 1, 151-158.

Grad, K. \& L. Ferjančič, 1974: Osnovna geološka karta Jugoslavije 1 : 100.000, list Kranj. Zvezni geološki zavod Beograd.

Gosse, J.C. \& F.M. Phillips, 2001: Terrestrial cosmogenic nuclides: theory and applications.- Quaternary Science Reviews, 20, 1475-1560.

Granger, D.E. \& P.F. Muzikar, 2001: Dating sediment burial with in-situ produced cosmogenic nuclides: theory, techniques, and limitations.- Earth \& Planetary Science Letters, 188, 269-281.

Häuselmann, P. \& D.E. Granger, 2005: Dating of caves by cosmogenic nuclides: method, possibilities, and the Siebenhengste example (Switzerland).- Acta carsologica, 34 (1), 43-50.

Häuselmann, P., Fiebig, M., Kubik, P.W. \& H. Adrian, 2007: A first attempt to date the original "Deckenschotter" of Penck \& Brückner with cosmogenic nuclides.- Quaternary International, 164-165, 33-42.

Jamšek Rupnik, P., Benedetti, L., Bavec, M. \& M. Vrabec, 2012: Geomorphic indicators of Quarternary activity of the Sava fault between Golnik and Preddvor.RMZ - Materials and geoenvironment, 59, 2(3), 299-314.

Jamšek Rupnik, P., Benedetti, L., Preusser, F., Bavec, M. \& M. Vrabec, 2013 : Geomorphic evidence of recent activity along the Vodice thrust fault in the Ljubljana Basin (Slovenia) a preliminary study.- Annals of geophysics, 56(6). S0680; doi:10.4401/ag-6252.

Kuščer, D., 1990: Kvartarni savski zasipi in neotektonika.- Geologija, 33, 299-313.

Nishiizumi, K., Winterer, E.L., Kohl, C.P., Klein, J., Middleton, R, Lal, D. \& J.R. Arnold, 1989: Cosmic ray production rates of ${ }^{10} \mathrm{Be}$ and ${ }^{26} \mathrm{Al}$ in quartz from glacially polished rocks.- Journal of Geophysical Research, 94, 17'907-17'915.

Pavich, M.J. \& N. Vidic, 1993: Application of paleomagnetic and ${ }^{10} \mathrm{Be}$ analyses to chronostratigraphy of Alpine glacio-fluvial terraces, Sava River Valley, Slovenia.- In: Swart, P. (ed.): Climate change in continental isotope records. Geophysical Monograph, $78,263-275$.
Penck, A. \& E. Brückner, 1909: Die Alpen in Eiszeiten.Tauchnitz, 1199, Leipzig.

Placer, L., 2008: Principles of the tectonic subdivision of Slovenia.- Geologija, 51(2), 205-217.

Prelovšek, M. \& T. Slabe, 2005: Geomorfologija in skalne oblike.- In: Kranjc, A. (ed.) Kraške kulturne pokrajine: edinstveni odnos med človekom in kraškim svetom [Karstic cultural landscapes: architecture of a unique relationship people - territory, Udin boršt]. Museo di Storia Naturale e Archeologia, Montebelluna, pp. 25-35.

Ribarič, V., 1982: Seismicity of Slovenia, Catalogue of earthquakes (792 A.D.-1981). Seismological Survey of Slovenia, Ljubljana. pp. 649.

Rižnar, I., Koler, B. \& M. Bavec, 2005: Identifikacija potencialno aktivnih struktur vzdolž reke Save na podlagi topografskih podatkov in podatkov nivelmanskega vlaka. = Identification of potentially active structures along the Sava River using topographic, and laveling line data.- Geologija, 48(1), 107-116.

Serpelloni, E., Faccenna, C., Spada, G., Dong, S. \& D. Williams, 2003: Vertical GPS ground motion rates in the Euro-Mediterranean region: New evidence of velocity gradients at different spatial scales along the Nubia-Eurasia plate boundary.- Journal of Geophysical research 118 (11), 6003-6024. 10.1002/2013JB010102

Stock, G.M., Granger, D.E., Sasowsky, I., Anderson, R.S. \& R.C. Finkel, 2005: Comparison of U-Th, paleomagnetism, and cosmogenic burial methods for dating caves: Implications for landscape evolution studies.- Earth and Planetary Science Letters, 236 (1-2), 388-403.

Šifrer, M., 1969: Kvartarni razvoj Dobrav na Gorenjskem.- Geografski zbornik, 11, 101-221.

Vidic, N.J., 1998: Soil-age relationships and correlations: comparison of chronosequences in the Ljubljana Basin, Slovenia and USA.- Catena, 34, 113-129.

Vidic, N.J. \& F. Lobnik, 1997: Rates of soil development of the chronosequence in the Ljubljana Basin, Slovenia.- Geoderma, 76, 35-64.

Žlebnik, L., 1971: Pleistocen Kranjskega, Sorškega in Ljubljanskega polja.- Geologija, 14, 5-51. 